\title{
Review
}

\section{United Kingdom Anti-crisis Alternative}

\author{
A. V. Kuznetsov ${ }^{a, \#}$ \\ ${ }^{a}$ Financial University under the Government of the Russian Federation, Moscow, 125993 Russia \\ e-mail: kuznetsov0572@mail.ru \\ Received September 24, 2021; revised December 10, 2021; accepted December 12, 2021
}

\begin{abstract}
The article deals with the factors that ensure the sustainability of the reproduction of the British socio-economic model in the long term. Some features of the conceptual role of the UK in the formation of the global world order were studied. The impact of the COVID-19 on the economy of the United Kingdom was shown and the reasons for the deepest decline in production in the history of the country were summarized. The factors of chronic decline in productivity on the British labor market and strategic approaches to solving this problem were presented. Some provisions of the Trade and Cooperation Agreement between the UK and the European Union are discussed. The concept of sovereign money is analyzed as a possible response of British economic experts to the challenges of modern crises.
\end{abstract}

Keywords: socio-economic modeling, financial innovation, technological transformation, COVID-19, UK economy, labor productivity, industrial strategy, EU-UK Trade and Cooperation agreement, sovereign money.

DOI: $10.1134 / \mathrm{S} 1019331621060174$

\section{INTRODUCTION}

The UK is the fifth largest economy in the world in terms of GDP [1] and the volume of exports [2] and it holds the first position in the world in terms of trade surplus in financial services [3, p. 8]. The United Kingdom is one of the least regulated economies [4] and is among the top five countries in terms of innovation development, attracting more foreign investment in R\&D than many of its major competitors, including Germany, France and China [5]. In spite of such high ranking demonstration, the year 2020 in the country was marked by a record drop in production, caused by the extremely negative reactions of market structures to coronavirus and Brexit. Now the UK government is using an ambitious industrial strategy the goal of which is to transform the country into the most innovative economy in the world by 2027 . It is quite probable that implementing the planned structural transformations and holding one of the top positions in the the global economy will force British politicians to turn to the time-tested experience of solving internal development tasks by working out innovative approaches to financial sector regulation and their popularization.

\footnotetext{
\# Aleksei V. Kuznetsov, Dr. Sci. (Econ.), is a Professor and Leading Researcher at the Financial University under the Government of the Russian Federation.
}

\section{A SYNTHESIS OF LIBERALISM AND DIRIGISME}

According to President of the Adam Smith Institute M. Pirie, the key to the success of the AngloSaxon model are its unique principles-adversarial principle and evolutionary principle [6]. Given the permanent influence of Great Britain on the global world order, it is difficult to overestimate the practical implementation of these principles. It is the United Kingdom that made a significant contribution into the formation of the international political system as well as the formation of the economic, financial, scientific, technological, informational and cultural image of the modern world.

It should be noted that maintaining internal political stability and influence in international relations was done at the cost of a firm combination of liberal and dirigistic methods in the regulation of economic activity [7]. For example, to prevent the destabilization of the economy after the collapse of the financial pyramid of the South Sea Company a law prohibiting the creation of new public joint stock companies was in action in England for a hundred years (1720-1825). Actively promoting the liberal ideas of Adam Smith, Britain was seen as the country with the most uncompromising protectionist policy towards the rest of the world until the middle of the 19th century [8]. After World War II, to compensate for the loss of the colonial income, the main sectors of the economy (including the Bank of England) were nationalized and 
extraordinary tax rates (reaching 98\%) on the income of the richest individuals were introduced [9, p. 501].

At the same time British politicians worked to create the most favorable regime for the influx of foreign capital into the country. The result of this painstaking work was the emergence of the first world monetary system with a key role of the pound sterling and the emergence of the largest international financial centre in the City of London. Let us emphasize that after the United States had surpassed Great Britain in terms of foreign trade in 1880 , the pound sterling retained its status as the leading reserve currency for more than half a century. Thus, in 1947 it accounted for more than $80 \%$ of international foreign exchange reserves $[10$, p. 10$]$ - in other words, politics sometimes plays a more important role than the size of the economy, business and finance.

The collapse of the British Empire, completed by the Suez Crisis, required new schemes for extracting financial profits from the rest of the world. In the time of the Bretton Woods system crisis and the oil price shocks of the 1970s the symbol of financial liberalization was the Eurodollar market in London, which allowed banks to accept deposits and issue loans in foreign currencies, bypassing national laws and regulations. In the 1980 s the policy of deregulation was continued by the Thatcher government, which extended neoliberal principles to stock trading, insurance and investment business, thus eliminating all possible obstacles to a large-scale inflow of capital into the British economy from other countries, primarily from the United States. In the 1990s the neoliberal paradigm was further developed within the framework of the Third Way doctrine, which actually legalized the offshore financial model of the global market with the key role of tax havens, the most significant of which were in direct or indirect British jurisdiction [11]. Thanks to these innovations, London has regained its right to be the largest international financial center. And to this day the British capital tops the list of the global cities that are the most favorable for the inflow of international investment [12, p. 7].

COVID-19 and Brexit brought an end to a halfcentury of neoliberal experiments that had let Britain to draw its energy from the outside world with virtually no limits. Obviously, the time has come when, in order to restore the economic dynamics, England will again have to turn to the time-tested methods of tight regulation of domestic economic activity.

\section{IMPACT OF COVID-19 ON THE UK ECONOMY}

The UK economy suffered immensely from the consequences of the coronavirus pandemic, which led to the deepest drop in GDP among the G7 countries, amounting to $21.2 \%$ in the first half of 2020 . Such negative market reaction to the consequences of the pandemic can be explained by a long period of the govern- ment's restrictive measures (lockdown), the extraordinary role of the service sector in the structure of the national economy and the deep integration of British business into the world economy.

During the first Covid wave, the isolation regime was introduced in the UK later (which is also associated with an increased number of deaths from the virus) and for a longer time than in some other European countries. The impact of the Covid shock on the economy has been uneven. The biggest decline was observed in tourism, transport and entertainment. Industries that were largely able to continue operation, observing social distancing rules, such as financial services, energy and agriculture proved to be relatively well protected from the effects of the pandemic.

It should be noted that British economy is extremely dependent on the service sector, which accounts for about $80 \%$ of GDP. In October 2020, in 45 out of 51 service sectors, the level of production was lower than in February 2020. The worst-hit areas were aviation $(-83.5 \%)$, entertainment industry $(-58.4 \%)$, railways $(-51.8 \%)$ and the hotel business $(-40.8 \%)$. A similar situation was observed in 27 out of 44 manufacturing industries. Among those, the largest drop was registered in the maintenance of aircraft $(-36.3 \%)$ and their production $(-22.4 \%)$, the production of weapons and ammunition (-24.8\%), and the production of coking coals and petroleum products $(-22.0 \%)$ [13].

The automobile sector plays an important role in the UK manufacturing industry, accounting for over $8 \%$ of total industrial production. The automobile industry in the United Kingdom is deeply integrated into the global economy: in 2017, $80 \%$ of the total number of cars produced in the country were exported (compared to 77\% in 2015) [14, p. 7]. The UK's automobile production in September 2020 was $5.0 \%$ lower than in the previous year, mostly due to a decline in shipments to the major foreign importing countries including China, the EU and the US [15].

In spite of a sharp decline in economic activity in the second quarter, employment remained at a high enough level. In October 2020, the unemployment rate was $4.9 \%$, just $1.1 \%$ higher than a year earlier. Government grants, loans, tax holidays and benefits to business have helped to retain employees and avoid bankruptcies. The rapid rise in unemployment (which took place in the United States) was prevented, in part, thanks to the Coronavirus Job Retention Scheme (CJRS). In order to preserve jobs under this scheme, the government offered to compensate $80 \%$ of wages (but not more than $£ 2500$ ) to employees of companies sent on forced leave under the lockdown conditions. Also, under the Self-Employment Income Support Scheme (SEISS), self-employed people have been able to receive a taxable subsidy in the amount of up to $80 \%$ of their previous average income over the past three years. 
The government allowed deferred tax payment of 40 billion pounds to legal entities. More than a million firms took loans against government guarantees, and for hotel companies the VAT was reduced from 20 to 5\%. The Bank of England has cut the interest rate twice since March from 0.75 to $0.1 \%$, and increased the purchase of corporate and government bonds within the framework of the "quantitative easing" policy to 895 billion pounds. Together, these measures helped to reduce the number of bankruptcies by almost a third compared to 2019. In spite of this support, the number of employees fell by 750000 from March to September 2020.

The introduction of the abovementioned government measures caused severe and growing damage to the national budget. The government allocated huge amounts of money to treat the coronavirus patients, control the spread of the coronavirus and mitigate its financial impact on households and businesses. The government's proactive fiscal measures can increase the budget deficit to 394 billion pounds (19\% of GDP) and debt growth to $105 \%$ of GDP - their highest indicators, respectively, from 1944-1945 and 1959-1960 fiscal years [16, p. 5].

The sharp rise in the ratio of public debt to GDP is favored by the fact that the government takes loans for up to three years at negative interest rates and is able to issue debt obligations with a maturity of 50 years and a service cost of less than $0.5 \%$ per annum. Besides, most of the UK government debt has a long maturity. In March 2020, 42\% of the debt portfolio liabilities had maturities over 15 years, while the average maturity of government bonds and treasury bills was 15 years. According to OECD experts, one of the measures to reduce the sensitivity of public debt to higher interest rates in the medium and long terms could be fixing a low interest rate on long-term loans to finance emergency spending [17, pp. 28-29].

\section{POOR PRODUCTIVITY PROBLEM}

Apart from the need to cope with the negative consequences of the Covid crisis, another key problem for the UK's economic development has been the chronic decline in labour productivity over the past decade, which is considered to be the deepest one since the start of the industrial revolution 250 years ago. British scholars tie the slowdown in productivity growth to the prolonged impact of the 2008 crisis on the financial system, poor achievements in computer technology in the recent years after their boom in the late 1990s and early 2000s, as well as the uncertainty of post-Brexit trade relations which undermine investment into business [18].

The slowdown in productivity growth is also characteristic for the United States and other developed economies, but in the UK this problem manifests itself most visibly: in terms of the growth rate of production per hour in the years 2008-2017 the country ranked 31st among 35 OECD countries. Given that the UK has a leading position in the ICT employment, where productivity growth is the highest, the decline in overall productivity looks paradoxical.

Among the leading British economists, there are two broad approaches to explaining this phenomenon. The first one focuses on supply factors, including the professional qualifications of employees. The second explanatory approach focuses on the demand factors associated with the financial crisis, austerity and other reasons for the slow growth in the demand in the past decade [19].

To drive productivity, the UK government since 2017 has been implementing the ambitious Industrial Strategy which should turn the UK into the most innovative economy in the world by 2027 . Accordingly, it is planned to increase the total investment in R\&D from 1.7 to $2.4 \%$ of GDP by 2027 . By 20242025 a gross capital investment of about 640 billion pounds is planned (an average of 5.8\% of GDP per year) [20]. The government is committed to becoming the first zero carbon emission economy in the world by 2050. It should be emphasized that the ambitious Industrial Strategy was adopted the following year after the UK referendum on EU membership (2016).

\section{THE POST-BREXIT FUTURE}

After four and a half years of tiring negotiations, the UK signed the Trade and Cooperation Agreement with the EU on December 24, 2020, which signaled the beginning of a new phase of trade relations in connection with the country's official withdrawal from the Union on January 31, 2020. We should remember that the first referendum on maintaining the membership took place as early as in 1975 . Since then various movements and organizations have held Eurosceptical views. It was for these purposes that the UK Independence Party (UKIP) was created in the early 1990s, which later received a significant part of the funds from the sources close to the City of London [21, p. 145].

Among the reasons for dissatisfaction with the UK's membership in the EU the ones most often mentioned were: common trade, fisheries and agricultural policy, the inefficiency of the pan-European fiscal and monetary systems, social democratic approaches to the employment market, excessive business regulation, negative trade balance [22, pp. 57-64].

Analyzing the Agreement, we can conclude that it includes the fundamental issues that have caused the greatest resentment of British Eurosceptics so far. On the other hand, most of the questions regarding the future relationship between the UK and the EU remain open, requiring additional negotiations and agreements. 
Thus, by its exit from the EU, the UK liberated itself from numerous pan-European restrictions and regulatory practices. At the same time, the country ceased to be a part of the Single European Marketthe "four freedoms" that ensure the unhindered movement of people, goods, services and capital within the single European space. The concept of the Single European Market was actively supported by the Thatcher government. Since its practical introduction in 1993, leading multinational companies, motivated by the elimination of tariff and non-tariff barriers, began to move their production facilities to the British Isles in order to have a guaranteed free access to the world's largest market of goods and services. Views were expressed that after Brexit, the common market model will cease to work [23]. However, the opposite happened-after 2016, the EU accelerated the conclusion of intercontinental trade and investment agreements, gradually including such significant regional players as Canada, Mexico, Mercosur, Japan, Singapore, Vietnam, Australia, New Zealand, and even China into the sphere of its economic interests.

It should be emphasized that the EU is the largest foreign economic partner of Great Britain-the volume of mutual trade between them in 2019 amounted to 668 billion pounds. At the same time, the UK has a negative trade balance with the EU, reaching a record 79 billion pounds. On the other hand, the UK registered a record positive balance of 51.7 billion pounds in trade with the United States though the trade turnover is almost three times less than with the EU (232 billion pounds) [24].

One of the main complaints of the United Kingdom at the time of the EU membership was that the latter was a customs union, not a free trade zone, which did not allow the UK to conclude profitable trade agreements with other countries, primarily the United States, on its own. As a Brexit supporter, Donald Trump promised that the United States would conclude a profitable trade deal with the UK after it leaves the European Union. However, President-elect J. Biden called Brexit a mistake and ruled out the possibility of new trade agreements with any country until, he said, the United States improves its competitiveness at home [25].

The UK is home to the largest number of headquarters and subsidiaries of the biggest multinational companies, including the leading European manufacturers of goods and services. In terms of the accumulated volume of incoming foreign direct investment (2.1 trillion dollars in 2019), the United Kingdom is ahead of all other EU countries, second only to the United States in this indicator [26]. Thus it is difficult to imagine that the formal withdrawal of the UK from the Single European Market would affect big business in the extremely negative way, given the enormous political influence of these companies in their countries.
As a result, neither party is interested in the worsening of trade relations. However, the Agreement does not look so unambiguous. For example, even though an agreement was reached on the tariff-free trade, but if one of the parties departs from common standards as of December 31, 2020, a dispute resolution mechanism (the Joint Partnership Council) in the form of new tariffs can be activated. At the same time, the European Court of Justice will no longer play a key role in monitoring the implementation of the Agreement. However, it will remain competent in Northern Ireland, which, in accordance with the terms of the Agreement, will continue to be subject to the rules of the EU's single market and customs union [27].

The agreement does not specify the future role of the City of London as the largest financial centre of Europe and one of the leading centers of the world. The UK plays a key role in the management of European capital, OTC derivatives and foreign exchange trading. Thus, the City of London clears $75 \%$ of eurodenominated financial derivatives equivalent to about 1 quadrillion dollars, and banks located in the UK manage $40 \%$ of European assets and $60 \%$ of European capital markets [28, pp. 82-83].

London provides global financial intermediation services to European investors and provides access to European markets to non-EU countries. In accordance with the Agreement, beginning from 2021 financial institutions located in the UK will lose the socalled "European passport," which gives the right to provide financial services anywhere in the European Union without any additional approvals from the host party. British companies' access to EU markets will now be governed by the principle of "equivalence" applied to third countries unless an additional agreement is signed between the United Kingdom and the European Union facilitating access to European financial markets for British companies. According to the British government's estimates, the loss of the European passport may increase the costs of British operators of financial services by $13 \%[29$, p. 44]. Nevertheless, in the long run, the City of London will most probably remain attractive to European clients, given the advantages of the UK regulatory and institutional framework, including protection of the rights of creditors and shareholders, regulations on tax and on employment, as well as the historical volume and liquidity of the London market.

On the whole, it is now hard to predict the future of EU-UK relations judging by the Agreement alone. One thing is clear-Brexit pushed the EU to open its economic space to the rest the world, bringing closer the fulfilment of the British conservatives' dream - a global free trade zone [30, pp. 98-99]. It is beyond doubt that the year 2020 was a turning point not only for the UK, but for the entire world. Brexit and COVID-19 confirmed the complete obsolescence of the neoliberal paradigm of financial globalization. 
The creation of a multipolar world on a new technological platform requires a new social contract, which seems impossible in the current configuration of the world monetary system based on credit money and American-centric offshore financial institutions.

As mentioned above, Britain has a unique experience in crisis management through the development and global distribution of innovative financial schemes that allow to stabilize the domestic economic situation with the resources of the rest of the world [31]. We cannot exclude that the post-neoliberal concept of financial sector regulation will also be based on the ideas of British experts. Let us look at one of these ideas in more detail.

\section{SOVEREIGN MONEY CONCEPT}

In Great Britain-the mother country of the modern central bank-there is now an active discussion going on various options for returning full state control over monetary circulation. Among others, the former Governor of the Bank of England M. King proposes to reform the modern banking system. According to M. King, in the future the risks created by the transformation of individuals' insured deposits into highrisk loans should be born by the financial institutions that gain profit from such "financial alchemy" [32].

M. King proposes to create two types of banks to prevent systemic risks: narrow banks and wide banks. Narrow banks must insure their deposits with 100\% reserves in the form of highly liquid safe assets such as government securities and mandatory reserves held at the central bank. The income of narrow banks should come exclusively from the provision of payment services. Along with narrow banks, M. King proposes to create "wide" banks, which today include a variety of non-banking financial institutions. Wide banks can finance all other types of activities, and above all provide high-risk loans to the private sector. However, unlike narrow banks, they cannot accept demand deposits or short-term deposits. Instead, wide banks must finance high-risk loans by issuing shares or longterm debt. This system should prevent financial abuse resulting from the severing of the link between money creation and credit creation.

The second aspect of the reform proposed by M. King is the change in the function of the central bank as lender of last resort. M. King proposes turning the central bank into a "pawnbroker for all seasons." According to this innovative approach, any bank (or other financial intermediary) must reserve a part of its assets from the central bank in advance for their subsequent use as collateral (with a discount if necessary) against the future lending of liquid funds. Accordingly, the bank's liquid assets must exceed its liquid liabilities. According to M. King, such an approach can eliminate the problem of moral hazard associated with the performance of the central bank as the lender of last resort, and significantly simplify financial regulation [33].

M. King's proposals are only a part of a broader concept of "sovereign money" which proposes to reform the banking system in such a way as to deprive private banks of the opportunity to create new money altogether. New money in the form of bank deposits is created when banks issue loans and is destroyed when the borrower repays the loans. The problem is that most of the new money created with the help of bank lending goes not to finance production or activities indirectly related to it, but to buy existing assets-for example, real estate or securities, in order to resell them at higher prices. The turn of the central banks to such unconventional monetary policy as "quantitative easing" and near-zero interest rates does not seem to be a fully adequate answer to this problem.

The idea of "sovereign money" originated in the work of the English scientist, Nobel laureate in chemistry F. Soddy, which was published in 1926. During the Great Depression, American economists F. Knight and H. Simons presented Soddy's ideas to US President Franklin D. Roosevelt (later they were popularized by I. Fischer). Since then, the idea of "sovereign money" has been developed in various ways by M. Friedman, D. Tobin, H. Minsky, D. Kay and L. Kotlikoff.

Quite recently the economists of the International Monetary Fund tested I.Fischer's initial model of sovereign money on the indicators of the modern US economy and found a "solid confirmation" of all the declared advantages and additional positive effects of this model [34]. Since then, the idea of sovereign money, in addition to the former Governor of the Bank of England, M. King, was supported and developed by the chief economics commentator of the Financial Times M. Wolf, the former chairman of the UK Financial Services Authority A. Turner, as well as Vice-President of the European Central Bank Vitor Constâncio [35].

Technically, the idea of sovereign money is extending the exclusive right to create money which is reserved by constitution to the central banks of many countries, also to the balance sheets of commercial banks, which would deprive the latter of the opportunity to create money through demand deposits and term bank deposits.

In the system of sovereign money, the creation of required reserves at central banks by commercial banks becomes redundant, because all money acquires the status of reserve money. Due to a significant simplification of the banking business and a bank's balance in the system of sovereign money, the proposal to create a system of $100 \%$ bank reserve seems inappropriate [36, pp. 45-47].

The main limitation of the sovereign money system is that the central bank, acting as the central planner for money creation, needs to have much more infor- 
mation than it has under present conditions. Another limitation is that commercial banks, due to a lack of central bank money, cannot always take advantage of attractive lending opportunities. Consequently, the elasticity of bank lending in the real economy is generally higher in the current system than in the sovereign money system [37].

Characteristically, the concept of sovereign money does not contradict the tendency of transferring the world economy to a digital platform, which implies an unprecedented centralization of the monetary system if money issuers gain unlimited access to Big Data. It should be noted that the UK is leading among the largest economies of Europe in the level of digitalization of the national economy [38]. In the years 20092019 the share of cash payments in the United Kingdom declined from 58 to $23 \%$ [39, p. 3]. These trends are in tune with the preparatory work of the Bank of England to transfer the national currency to a digital basis [40]. The digitalization of the pound sterling is seen as a tool that will increase the security and the efficiency of payments, simplify international transfers, reduce the risks of issuing private currencies, and activate the digitalization of the economy.

It can be assumed that even a partial implementation of the concept of sovereign money, in conjunction with the successful introduction of the digital pound, can not only provide Great Britain with financial support for large-scale national projects in the era of the fourth industrial revolution, but also serve as an example of anti-crisis regulation for other countries.

\section{CONCLUSIONS}

For centuries financial innovation has been a constant factor in restoring the UK's leading position in the international arena. Until now, the political and economic stability of the British state has largely depended on the consistent adherence to the key principles of the Anglo-Saxon socio-economic model. The future will show how much the adherence to these principles will help the United Kingdom keep its role as a mediator of the relations between the Old and the New Worlds in the conditions of the emerging technological paradigm of the polycentric world.

\section{ACKNOWLEDGMENTS}

The article is based on the results of research carried out at the expense of budgetary funds on the state order of the Financial University on an applied research topic: "Development of monetary polycentrism and regionalization in the process of transformation of the world monetary and financial system.”

\section{REFERENCES}

1. World economic outlook database, October 2020. https://www.imf.org/en/Publications/WEO/weo-database/2020/October. Cited September 1, 2020.

2. Exports of Goods and Services. https://data.worldbank.org/indicator/BX.GSR.GNFS.CD. Cited September 1, 2021.

3. Key facts about the UK as an International Financial Centre 2020, December 2020. https://www.thecityuk.com/research/key-facts-about-the-uk-as-an-international-financial-centre-2020/. Cited September 1, 2021.

4. Doing business 2020, October 24, 2019. https://www.doingbusiness.org/en/reports/global-reports/doing-business-2020. Cited September 1, 2021.

5. The Global Innovation Index 2020. https://www.globalinnovationindex.org/Home. Cited September 1, 2020.

6. M. Pirie, The Anglo-Saxon model of capitalism. https://madsen-pirie.com/the-things-that-i-do/communicating/the-anglo-saxon-model-of-capitalism/. Cited September 1, 2021.

7. E. S. Reinert, How Rich Countries Got Rich and Why Poor Countries Stay Poor (Constable, London, 2008).

8. H. J. Chang, Kicking Away the Ladder: How the Economic and Intellectual Histories of Capitalism Have Been Re-Written to Justify Neo-Liberal Capitalism (Anthem Press, London, 2002).

9. T. Piketty, Capital in the Twenty-First Century (Ad Marginem, Moscow, 2016) [in Russian].

10. B. Eichengreen, L. Chiţu, and A. Mehl, "Stability or upheaval? The currency composition of international reserves in the long run," European Central Bank Working Paper no. 1715 (2014). https://www.ecb.europa.eu/pub/pdf/scpwps/ecbwp1715.pdf. Cited September $1,2020$.

11. N. Shaxson, The Finance Curse: How Global Finance Is Making Us All Poorer (Bodley Head, London, 2018).

12. Winning in Growth Cities Report. 10 July 2019. https://www.cushmanwakefield.com/en/insights/winning-in-growth-cities. Cited September 1, 2020.

13. Office for National Statistics: Coronavirus and the impact on output in the UK economy: October 2020. https://www.ons.gov.uk/economy/grossdomesticproductgdp/articles/coronavirusandtheimpactonoutputintheukeconomy/october2020. Cited September 1, 2021.

14. T. Leeson, Brexit and the UK automotive industry: Understanding the impact.

https://bcuassets.blob.core.windows.net/docs/report-foropentext-deliverable-b-final-131880562823173347.pdf. Cited September 1, 2020.

15. Office for National Statistics: GDP Quarterly National Accounts, UK: July to September 2020. https://www.ons.gov.uk/economy/grossdomesticproductgdp/bulletins/quarterlynationalaccounts/julytoseptember2020. Cited September 1, 2021.

16. Office for Budget Responsibility: Economic and fiscal Outlook, November 2020.

http://cdn.obr.uk/CCS1020397650-001_OBR-Novem- 
ber2020-EFO-v2-Web-accessible.pdf. Cited September 1, 2021.

17. OECD Economic Surveys: United Kingdom 2020 (OECD Publishing, Paris, 2020). Cited September 1, 2021. https://doi.org/10.1787/2f684241-en

18. R. Partington, "UK productivity slowdown worst since Industrial Revolution: Study," Guardian, Feb. 3 (2020). https://www.theguardian.com/business/2020/feb /03/uk-productivity-slowdown-worst-since-industrial-revolution-study. Cited September 1, 2021.

19. E. Ilzetzki, If the UK is high tech, why is productivity growth slow? https://blogs.lse.ac.uk/businessreview/2020/03/07/if-the-uk-is-high-tech-why-is-productivity-growth-slow-economists-weigh-in/. Cited September 1, 2020.

20. Industrial strategy: Building a Britain fit for the future, November 27, 2017. https://www.gov.uk/government/publications/industrial-strategy-building-a-britain-fit-for-the-future. Cited September 1, 2020.

21. D. MacShane, Brexit: How Britain Will Leave Europe (I.B. Tauris, London, 2016).

22. Brexit Economic Aspects, Ed. by A. I. Bazhan (Inst. Evropy RAN, Moscow, 2017), Report no. 345. [in Russian].

23. F. Islam, Adieu to the single market created by the UK, January 1, 2021. https://www.bbc.com/news/business55494101. Cited September 1, 2021.

24. Office for National Statistics: UK Balance of Payments, The Pink Book: 2020.

https://www.ons.gov.uk/economy/nationalaccounts /balanceofpayments/bulletins/unitedkingdombalanceofpaymentsthepinkbook/2020. Cited September 1, 2021.

25. M. Landler and S. Castle, "Britain and E.U. reach landmark deal on Brexit," New York Times, Dec. 24 (2020).

https://www.nytimes.com/2020/12/24/world/europe /brexit-trade-deal-uk-eu.html. Cited September 1, 2020.

26. World Investment Report 2020. https://unctad.org/webflyer/world-investment-report-2020. Cited September 1, 2021.

27. C. Morris, Brexit deal: What is in it? December 28, 2020. https://www.bbc.com/news/55252388. Cited September 1, 2020.

28. V. Y. Pishchik, A. V. Kuznetsov, and P. V. Alekseev, "European economic and monetary union: 20 years af- ter,” World Econ. Int. Rel. 63 (9), 76-85 (2019) [in Russian].

29. EU exit long-term economic analysis, November 2018. https://assets.publishing.service.gov.uk/government /uploads/system/uploads/attachment_data/file/760484 /28_November_EU_Exit_-_Long-term_economic _analysis_1_._pdf. Cited September 1, 2020.

30. M. A. Lipkin, Britain in Search of Europe: A Long Road to the EEC (1957-1974) (Aleteiya, St. Petersburg, 2009) [in Russian].

31. P. Temin and D. Vines, The Leaderless Economy: Why the World Economic System Fell Apart and How to Fix It (Izd. In-ta Gaidara, Moscow, 2015) [in Russian].

32. M. King, The end of Alchemy: Money, Banking, and the Future of the Global Eonomy (Little, Brown Book Group, London, 2016).

33. K. L. Kliesen, "The end of alchemy: Money, banking, and the future of the global economy," Business Economics 52 (3), 181-183 (2017).

34. M. Kumhof and J. Benes, "The Chicago plan revisited," IMF Working Paper no. 12/202 (2012).

https://www.imf.org/en/Publications/WP/Issues/2016/12/31/The-Chicago-Plan-Revisited-26178. Cited September 1, 2021.

35. B. Dyson, G. Hodgson, and F. Van Lerven, Sovereign money: An introduction. https://positivemoney.org /our-proposals/sovereign-money-introduction/. Cited September 1, 2020.

36. C. Felber, Money: The New Rules of The Game (Springer, Vienna, 2017).

37. H. Gersbach, Sovereign money: A challenge for science, October 2018. https://voxeu.org/article/sovereignmoney-challenge-science. Cited September 1, 2020.

38. The digital economy and society index. https://ec.europa.eu/digital-single-market/en/digital-economy-andsociety-index-desi. Cited September 1, 2020.

39. UK Payment Markets Summary 2020, June 2020. https://www.ukfinance.org.uk/system/files/UK-Payment-Markets-Report-2020-SUMMARY.pdf. Cited September 1, 2021.

40. Central Bank digital currency: Opportunities, challenges, and design, March 2020. https://www.bankofengland.co.uk/-/media/boe/files/paper/2020/centralbank-digital-currency-opportunities-challenges-anddesign.pdf. Cited September 1, 2020. 